\title{
Electronic Cigarettes Use and Intention to Cigarette Smoking among Never-Smoking Adolescents and Young Adults: A Meta-Analysis
}

\author{
Jieming Zhong ${ }^{1,+}$, Shuangshuang Cao ${ }^{2,+}$, Weiwei Gong ${ }^{1}$, Fangrong Fei ${ }^{1}$ and Meng Wang ${ }^{1, *}$ \\ 1 Zhejiang Provincial Center for Disease Control and Prevention, 3399 Binsheng Road, Hangzhou 310051, \\ China; jmzhong@cdc.zj.cn (J.Z.); wwgong@cdc.zj.cn (W.G.); frfei@cdc.zj.cn (F.F.) \\ 2 Yidu Central Hospital of Weifang, 4138 Linglong Road, Qingzhou 262500, China; caoss1234@163.com \\ * Correspondence: mwang@cdc.zj.cn; Tel.: +86-571-8711-5164; Fax: +86-571-8711-5163 \\ + These authors contributed equally to this work.
}

Academic Editor: Paul B. Tchounwou

Received: 23 February 2016; Accepted: 28 April 2016; Published: 3 May 2016

\begin{abstract}
Electronic cigarettes (e-cigarettes) use is becoming increasingly common, especially among adolescents and young adults, and there is little evidence on the impact of e-cigarettes use on never-smokers. With a meta-analysis method, we explore the association between e-cigarettes use and smoking intention that predicts future cigarette smoking. Studies were identified by searching three databases up to January 2016. The meta-analysis results were presented as pooled odds ratio (OR) with $95 \%$ confidence interval (CI) calculated by a fixed-effects model. A total of six studies (91,051 participants, including 1452 with ever e-cigarettes use) were included in this meta-analysis study. We found that never-smoking adolescents and young adults who used e-cigarettes have more than 2 times increased odds of intention to cigarette smoking ( $\mathrm{OR}=2.21,95 \% \mathrm{CI}: 1.86-2.61$ ) compared to those who never used, with low evidence of between-study heterogeneity $\left(p=0.28, \mathrm{I}^{2}=20.1 \%\right)$. Among never-smoking adolescents and young adults, e-cigarettes use was associated with increased smoking intention.
\end{abstract}

Keywords: electronic cigarette; smoking intention; meta-analysis

\section{Introduction}

Although reductions in the smoking prevalence were observed at global level since 1980, the tobacco pandemic remains a threat to the health of the world's population [1]. As the second most important risk factor for global disease burden, tobacco use accounted for 6.1 million deaths and 143.5 million disability-adjusted life-years (DALYs) across the world in 2013 [2]. Currently, nations are striving to curb tobacco use and reduce its harm. Considering that the majority of smokers begin to smoke during their adolescence [3], preventing youth initiation and transition to established smoking are critical public health issues that deserve more attention.

Smoking intention, defined as the lack of a firm commitment not to smoke among never-smokers, is strongly predictive of future established smoking [4-6]. A growing body of literature has identified varying factors associated with smoking intention, such as parental or peer smoking, exposure to secondhand smoke inside or outside the home, pro-tobacco advertising, and school connectedness [7-9]. However, additional studies are warranted in this direction with the advent of electronic cigarettes (e-cigarettes).

E-cigarettes are battery-powered nicotine-delivery devices that mimic conventional cigarettes by vaporizing a liquid mixture consisting of propylene glycol, glycerin, flavorings, nicotine, and other chemicals. Since invented in 2003, e-cigarettes have been hotly debated regarding the safety and 
efficacy for smoking cessation [10-14]. While arguments between both sides of advocates and critics persist, e-cigarettes use has rapidly increased globally [15], especially among youth [16,17]. Moreover, given the majority of users among youth are never-smokers [18,19], whether youth use of e-cigarettes may serve as a gateway to cigarette smoking has been discussed in previous studies [20,21]. However, up to date, the effect of youth e-cigarettes use on subsequent cigarette smoking remains unclear. In the present study, we use meta-analysis method to explore the association between e-cigarettes use and smoking intention among adolescents and young adults to contribute to the much-needed evidence.

\section{Materials and Methods}

\subsection{Literature and Search Strategy}

Epidemiological studies on the association between e-cigarettes use and smoking intention were searched through three databases (PubMed, Springer Link, and Elsevier) from 2003 to January 2016. Smoking intention was defined as the lack of a firm commitment not to smoke among never-smokers, with the answer yes to one or two questions derived from previous studies [4-6]: "Do you think you will smoke a cigarette in the next year (or two years)?" and "If one of your best friends were to offer you a cigarette, would you smoke it?" Detailed definitions were shown in Table 1. The main search terms included "electronic cigarette", "e-cigarette", "electronic nicotine delivery systems", "vaping", "vaper", "vapor", "smoking intention", "susceptibility to smoke", "openness to smoke", and "willingness to smoke". Reference lists of retrieved literature were also screened.

The present study was carried out following the Meta-analysis of Observational Studies in Epidemiology (MOOSE) guidelines [28].

\subsection{Inclusion Criteria and Data Extraction}

Selected studies in this meta-analysis met the following criteria: (1) reporting the association between e-cigarettes use and smoking intention; (2) providing the effect value with $95 \%$ confidence interval (CI) or data to calculate these; (3) the study population must be never-smokers. Two authors independently assessed the eligibility of studies and extracted information from each eligible study. The information included (1) name of the first author; (2) year of publication; (3) participants and sample size; (4) data source and location; (5) study type; (6) measures definition; (7) variables adjusted.

\subsection{Statistical Analysis}

Heterogeneity between studies was assessed using a Q-test and the $\mathrm{I}^{2}$ statistic [29]. For the Q-test, $p$ value $<0.05$ was considered statistically significant. The low, moderate, and high degrees of heterogeneity correspond to $\mathrm{I}^{2}$ values of $25 \%, 50 \%$, and $75 \%$, respectively. If there was significant heterogeneity, a random-effects model would be used to assign the weight of each study according to the DerSimonian-Laird method [30]. If there was evidence of no heterogeneity, we used a fixed-effects model with effect estimates that were given equal weight to the inverse variance of the study. To test robustness of the present meta-analysis result, a sensitivity analysis was performed with excluding outliers. Publication bias was assessed by Egger's regression asymmetry test ( $p$ value $<0.05$ was considered statistically significant). All the statistical analyses were conducted with STATA Version 11 software (StataCorp LP, College Station, TX, USA). 
Table 1. Information of the studies included in the meta-analysis.

\begin{tabular}{|c|c|c|c|c|c|c|}
\hline Study (year) & Source & $\begin{array}{l}\text { Participants (No. of } \\
\text { Ever e-Cigarettes } \\
\text { Users/Participants) }\end{array}$ & Location & Design & Measures & Variables Adjusted \\
\hline $\begin{array}{l}\text { Bunnell RE, et al. } \\
\text { (2015) [22] }\end{array}$ & $\begin{array}{l}\text { 2011-2013 National } \\
\text { Youth Tobacco } \\
\text { Survey (NYTS) }\end{array}$ & $\begin{array}{l}\text { Students in grades } \\
6-12(541 / 43,873)\end{array}$ & USA & Cross-sectional & $\begin{array}{l}\text { 2011-2013 National Youth Tobacco Survey (NYTS) } \\
\text { Smoking intentions: "Do you think you will smoke a cigarette in the next } \\
\text { year?" and "If one of your best friends were to offer you a cigarette, would } \\
\text { you smoke it?" Response options included: "definitely yes", "probably yes", } \\
\text { "probably not", and "definitely not". Those who responded "definitely not" } \\
\text { to both intentions questions were classified as not having intentions; } \\
\text { otherwise, respondents were classified as having intentions. } \\
\text { Ever electronic cigarettes use: students who selected " "lectronic Cigarettes or } \\
\text { E-cigarettes, such as Ruyan or NJOY" to the question "Which of the following } \\
\text { products have you ever tried, even just one time?" were considered ever } \\
\text { e-cigarette users. }\end{array}$ & $\begin{array}{l}\text { Sex, race/ethnicity, school } \\
\text { level, number of distinct } \\
\text { sources of pro-tobacco } \\
\text { advertisement exposure, } \\
\text { presence of a tobacco user } \\
\text { in the household, and } \\
\text { survey year }\end{array}$ \\
\hline $\begin{array}{l}\text { Coleman BN, et al. } \\
\text { (2015) [23] }\end{array}$ & $\begin{array}{l}\text { 2012-2013 National } \\
\text { Adult Tobacco } \\
\text { Survey (NATS) }\end{array}$ & $\begin{array}{l}\text { Young adults aged } \\
18-29 \text { years } \\
(341 / 4310)\end{array}$ & USA & Cross-sectional & $\begin{array}{l}\text { 2012-2013 National Adult Tobacco Survey (NATS) } \\
\text { Openness to smoking: "Do you think you will smoke a cigarette soon?" and } \\
\text { "Do you think you will smoke a cigarette in the next year?" Response options } \\
\text { were: "Definitely yes", "Probably yes", "Probably not", and "Definitely not". } \\
\text { A binary composite variable was created, and those who responded with any } \\
\text { response option other than a firm intention not to smoke ("Definitely not") } \\
\text { were categorized as being open to smoking cigarettes and, therefore, } \\
\text { considered at risk for future smoking. } \\
\text { Ever electronic cigarettes use: Those who had heard of electronic cigarettes or } \\
\text { e-cigarettes and answered "yes" to the question "Have you ever used an } \\
\text { electronic cigarette, even just one time in your entire life?" }\end{array}$ & $\begin{array}{l}\text { Sex, age group, } \\
\text { race/ethnicity, educational } \\
\text { attainment, US Census } \\
\text { region, ever use of } \\
\text { smokeless tobacco, ever use } \\
\text { of hookah, ever use of } \\
\text { cigars, and ever } \\
\text { experimentation } \\
\text { with cigarettes }\end{array}$ \\
\hline $\begin{array}{l}\text { Wang MP, et al. } \\
\text { (2015) [24] }\end{array}$ & $\begin{array}{l}\text { 2012-2013 Youth } \\
\text { Smoking Survey }\end{array}$ & $\begin{array}{l}\text { Secondary } 1 \text { to } 6 \\
\text { students with mean } \\
\text { age of } 14.6 \text { years } \\
(59 / 38,398)\end{array}$ & $\begin{array}{l}\text { Hong } \\
\text { Kong }\end{array}$ & Cross-sectional & $\begin{array}{l}\text { 2012-2013 Youth Smoking Survey } \\
\text { Smoking intentions: Students reported whether they would smoke in the next } \\
12 \text { months, and when cigarettes were offered by one of their good friends in } \\
\text { two separate items each with four response options of "definitely not", } \\
\text { "probably not", "probably yes", and "definitely yes". Those who chose } \\
\text { "definitely not" for both questions were regarded as having no intention to } \\
\text { smoke and otherwise as having an intention to smoke. } \\
\text { Electronic cigarette use: Students who reported e-cigarettes use in the past } 30 \\
\text { days, even one puff. }\end{array}$ & $\begin{array}{l}\text { Sex, age, perceived family } \\
\text { affluence, peer smoking, } \\
\text { parental smoking, and } \\
\text { school clustering effect }\end{array}$ \\
\hline
\end{tabular}


Table 1. Cont.

\begin{tabular}{|c|c|c|c|c|c|c|}
\hline Study (year) & Source & $\begin{array}{l}\text { Participants (No. of } \\
\text { Ever e-Cigarettes } \\
\text { Users/Participants) }\end{array}$ & Location & Design & Measures & Variables Adjusted \\
\hline $\begin{array}{l}\text { Moore GF, et al. } \\
\text { (2014) [25] }\end{array}$ & $\begin{array}{l}\text { 2014 Child exposure } \\
\text { to Environmental } \\
\text { Tobacco Smoke } \\
\text { (CHETS) Wales } 2\end{array}$ & $\begin{array}{l}\text { 10-11 year-old } \\
\text { children (77/1467) }\end{array}$ & Wales & Cross-sectional & $\begin{array}{l}2014 \text { Child exposure to Environmental Tobacco Smoke (CHETS) Wales } 2 \\
\text { Smoking intentions: Future intentions were measured by the question 'Do } \\
\text { you think you will smoke in } 2 \text { years' time?', with response options of } \\
\text { 'definitely yes',' 'probably yes', 'maybe or maybe not', 'probably no', and } \\
\text { Elefinitely no'. } \\
\text { e-ciganic cigarettes use: Children were asked 'Have you ever used an } \\
\text { once'. Children were classified as having used an e-cigarette if they } \\
\text { responded 'yes, once' or 'yes, more than once'. E-cigarettes were defined as } \\
\text { electronic versions of cigarettes which do not give off smoke. }\end{array}$ & $\begin{array}{l}\text { Parents smoke/use } \\
\text { e-cigarettes, friends } \\
\text { smoking, sex, family } \\
\text { affluence Scale (FAS) }\end{array}$ \\
\hline $\begin{array}{l}\text { Wills TA, et al. } \\
\text { (2015) [26] }\end{array}$ & $\begin{array}{l}\text { Survey at four } \\
\text { public and two } \\
\text { private high schools }\end{array}$ & $\begin{array}{l}\text { High school students } \\
\text { with mean age of } 14.7 \\
\text { years }(418 / 2309)\end{array}$ & Hawaii & Cross-sectional & $\begin{array}{l}\text { Survey at four public and two private high schools in Hawaii } \\
\text { Willingness to smoking: "Suppose you were with a group of friends and there } \\
\text { were some cigarettes you could have if you wanted. How willing would you } \\
\text { be to _." The items were "Take one puff", "Smoke a whole cigarette", and } \\
\text { "Take some cigarettes to try later". Responses were on four-point scales with } \\
\text { response points: Not At All Willing (0); A Little Willing (1); Somewhat } \\
\text { Willing (2); and Very Willing (3). A composite score for willingness to smoke } \\
\text { was the sum of the three items ( } \alpha=0.91) \text {. } \\
\text { Electronic cigarettes use: The item on e-cigarettes was introduced with the } \\
\text { stem: "Which of the following is most true for you about smoking electronic } \\
\text { cigarettes (E-cigarettes, Volcanos)? (check one)". Responses were on a } \\
\text { seven-point scale with anchor points Never Smoked an E-cigarette in My Life } \\
\text { to Usually Smoke E-cigarettes Every Day. }\end{array}$ & $\begin{array}{l}\text { Gender, ethnicity, family } \\
\text { structure, parental } \\
\text { education, parental } \\
\text { support, parental } \\
\text { monitoring, } \\
\text { parent-adolescent conflict, } \\
\text { academic competence, } \\
\text { social competence, } \\
\text { sensation seeking, } \\
\text { rebelliousness, smoking } \\
\text { expectancies, prototypes of } \\
\text { smokers, peer } \\
\text { smoker affiliation }\end{array}$ \\
\hline $\begin{array}{l}\text { Primack BA, et al. } \\
\text { (2015) [27] }\end{array}$ & $\begin{array}{l}\text { Second and third } \\
\text { waves of the United } \\
\text { States-based } \\
\text { Dartmouth Media, } \\
\text { Advertising, and } \\
\text { Health Study }\end{array}$ & $\begin{array}{l}\text { Adolescents and } \\
\text { young adults aged } \\
16-26 \text { years }(16 / 694)\end{array}$ & USA & Longitudinal cohort & $\begin{array}{l}\text { Second and third waves of the United States-based Dartmouth Media, } \\
\text { Advertising, and Health Study } \\
\text { Smoking intentions: "If one of your friends offered you a cigarette, } \\
\text { "Would you try it?" and "Do you think you will smoke a cigarette sometime } \\
\text { in the next year?" Responses included "definitely yes", "probably yes", } \\
\text { "probably no", and "definitely no". Those who responded "definitely no" to } \\
\text { both measures are considered Non susceptible nonsmokers (NSNS), whereas } \\
\text { those who cannot rule out smoking are defined as susceptible. } \\
\text { Electronic cigarettes use: whether participants had ever used an e-cigarette at } \\
\text { baseline? (yes and no). }\end{array}$ & $\begin{array}{l}\text { Sex, age, race/ethnicity, } \\
\text { maternal education level, } \\
\text { sensation-seeking tendency, } \\
\text { parental smoking, close } \\
\text { friends smoking }\end{array}$ \\
\hline
\end{tabular}




\section{Results}

\subsection{Study Characteristics}

The process of study selection for this meta-analysis is shown in Figure 1. 20 articles were excluded from 31 potentially eligible studies because they were reviews, news, studies on model hypotheses, and/or published without English language. Additionally, it should be noted that four duplicate articles and one article that combined e-cigarettes with other alternative tobacco products were also excluded. The detailed information of studies was shown in Table 1. Briefly, a total of six studies were included in this meta-analysis of e-cigarettes use and smoking intention [22-27]. Among them, four studies were from the USA, one from China, and one from the UK. All the included studies reported the final estimates with adjustment for specified confounders.

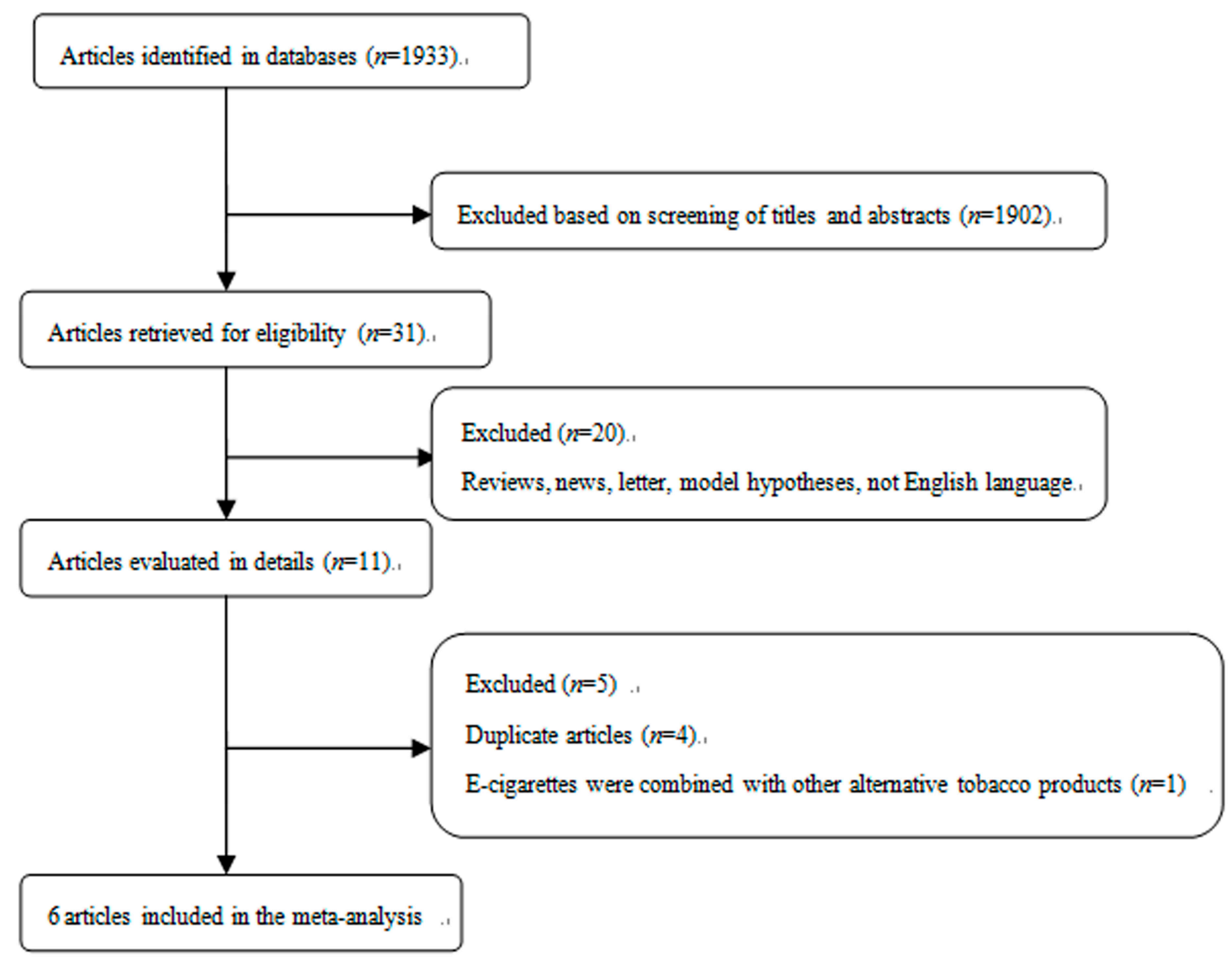

Figure 1. Selection of studies for inclusion in meta-analysis.

\subsection{Meta-Analysis of Association between E-Cigarettes Use and Smoking Intention}

With low degree of heterogeneity $\left(p=0.28, \mathrm{I}^{2}=20.1 \%\right.$ ), a fixed-effects model was used to calculate the pooled odds ratio (OR) with $95 \%$ confidence interval (CI) for e-cigarettes use. The pooled analysis showed that among never-smoking adolescents and young adults, individuals who used e-cigarettes had a greater smoking intention in the future $(\mathrm{OR}=2.21,95 \% \mathrm{CI}: 1.86-2.61$; Figure 2). After excluding the outlier, the sensitivity analysis result showed that the pooled OR was $2.46(95 \% \mathrm{CI}=2.01-3.01)$ and there was no significant study heterogeneity $\left(p=0.64, \mathrm{I}^{2}=0 \%\right)$. 


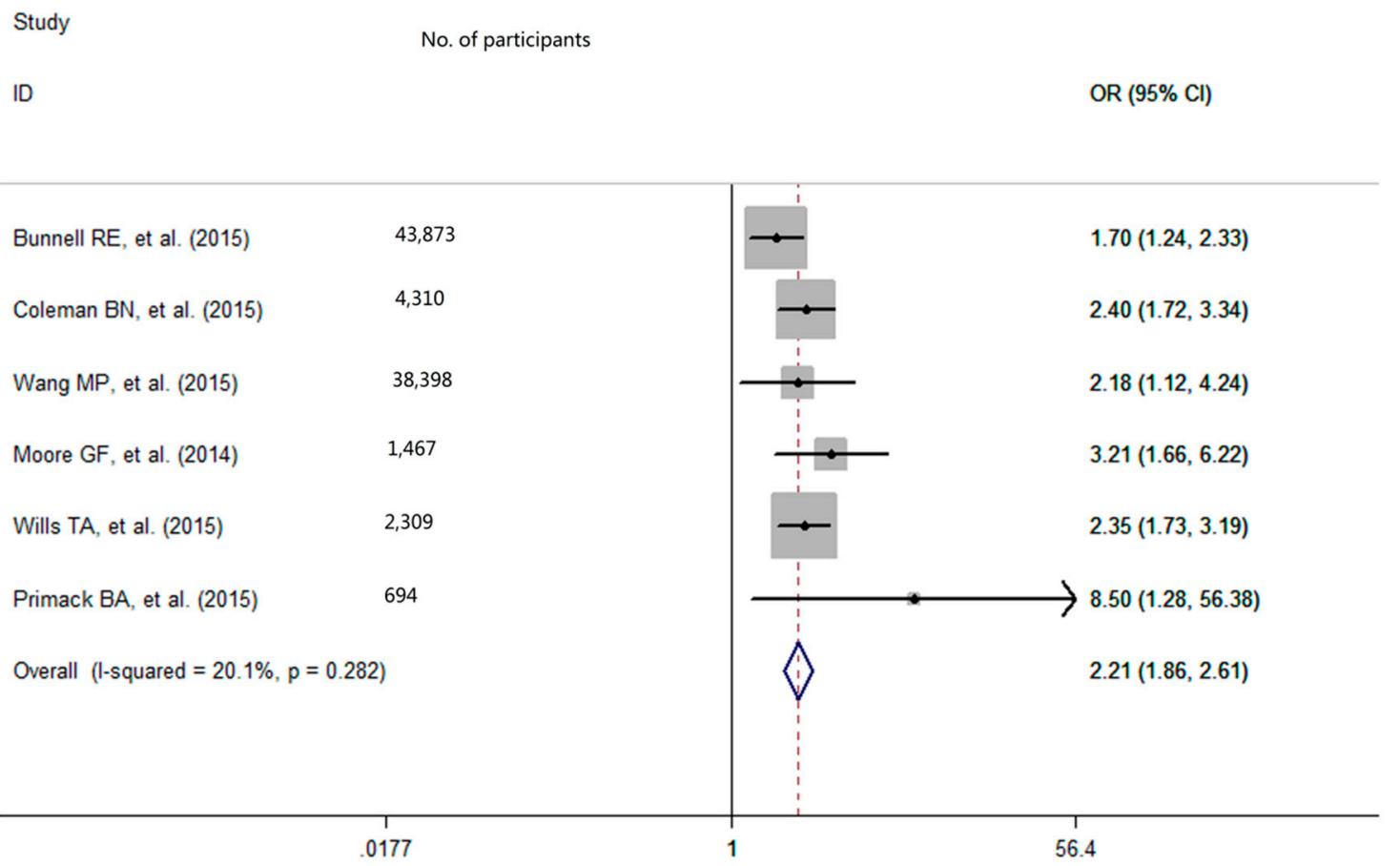

Figure 2. Effect of e-cigarettes use on smoking intention among never-smoking adolescents and young adults. OR refers to odds ratio; CI refers to confidence interval.

\subsection{Publication Bias}

As for the publication bias, the Egger's regression asymmetry test did not give a statistically significant result $(p=0.15)$.

\section{Discussion}

The present study uses meta-analysis method to provide a summary estimate of the effect of e-cigarettes use on smoking intention among never-smoking adolescents and young adults. With low evidence of between-study heterogeneity, findings from our meta-analysis confirm that never-smoking adolescents and young adults who used e-cigarettes have more than two times increased odds of intention to cigarette smoking ( $\mathrm{OR}=2.21,95 \% \mathrm{CI}: 1.86-2.61)$ in the future. Currently, there is considerable controversy about the health effects of e-cigarettes and one potential risk that e-cigarettes may become a new gateway to cigarette use among never-smokers has been identified as a concern by public health professionals [31,32]. As smoking intention is a strong predictor of future established smoking [4-6], our findings, in a way, add some tentative support for the probability that e-cigarettes use encourages the cigarette smoking initiation among never-smoking adolescents and young adults.

Although mechanisms accounting for the effect of e-cigarettes use on cigarette smoking initiation are complicated and still remain unclear, it is plausible that the nicotine exposure from e-cigarettes may play an important role in the "gateway effect". As a nicotine-delivery product, e-cigarettes may serve as a "nicotine starter" [27]. Adolescents, who have developing brains, are especially sensitive to nicotine exposure [12], which can create nicotine dependence and lead youth to use tobacco products [33,34]. Currently, new-generation e-cigarettes have evolved to be more efficient and nicotine delivery from some devices may approach or even exceed that of a tobacco cigarette [35,36]. In theory, the "gateway effect" would be more apparent in the future. Additionally, secondhand tobacco smoke (SHS) is an important contributor to nicotine and may potentiate the smoking initiation. A recent systematic review reveals positive associations between smoking initiation among nonsmokers and SHS and nicotine dependence, [37]. E-cigarettes, with some of mainstream vapor exhaled, the secondhand exposure to bystanders is no doubt inevitable and has been identified as a source of nicotine [38,39]. 
Hence, we posit that the same process may promote youth who used e-cigarettes to cigarette smoking initiation. However, given that SHS is a significant public health problem among never-smoking adolescents [40], the effect of nicotine from e-cigarettes vapor on smoking initiation may be confounded by SHS inevitably. Except for the biological mechanism of nicotine, psychological mechanism is also possible. Studies have shown that the greater possibility of e-cigarette use is associated with increased exposure to parental or peer smoking, which may foster smoking susceptibility [40-42], suggesting that e-cigarette use is likely to be a proxy for influences and pressures from family and peer.

The results from our meta-analysis study are subject to several limitations. Firstly, our literature searching was conducted through only three databases and the possible bias was inevitable. Secondly, given that most of the included studies are cross-sectional studies in the current meta-analysis, we cannot infer whether the association between e-cigarettes use and cigarette smoking initiation is causal or not, and as such, more prospective studies are warranted. Thirdly, the data was self-reported and susceptible to misreporting. Fourthly, due to a limited number of participants who ever used e-cigarettes, the observed association between ever e-cigarettes use and smoking intention should be interpreted with caution.

\section{Conclusions}

From a public health perspective, our findings that e-cigarettes use by never-smoking adolescents and young adults is associated with cigarette smoking intention have important implications for the debates on the benefits and risks of e-cigarettes. In order to reduce the smoking intentions of youth and prevent them from initiating the first cigarette, we propose that prevention efforts around e-cigarettes restrictions should be enhanced.

Acknowledgments: The study was sponsored by "Medicine and Health Care in Zhejiang Province Science and Technology Plan" (Grant number: 2015KYB084).

Author Contributions: Meng Wang designed the study and collected, analyzed the data with Shuangshuang Cao, Weiwei Gong, and Fangrong Fei. Jieming Zhong gave much advice and directions in both study design and preparing of the manuscript. All the authors have read and approved the final submitted version.

Conflicts of Interest: The authors declare no conflict of interest.

$\begin{array}{ll}\text { Abbreviations } & \\ \text { E-cigarettes } & \text { Electronic cigarettes } \\ \text { OR } & \text { Odds ratio } \\ \text { RR } & \text { Relative risk } \\ \text { CI } & \text { Confidence interval } \\ \text { DALYs } & \text { Disability-adjusted life-years } \\ \text { SHS } & \text { Second hand tobacco smoke }\end{array}$

\section{References}

1. Ng, M.; Freeman, M.K.; Fleming, T.D.; Robinson, M.; Dwyer-Lindgren, L.; Thomson, B.; Wollum, A.; Sanman, E.; Wulf, S.; Lopez, A.D.; et al. Smoking prevalence and cigarette consumption in 187 countries, 1980-2012. JAMA 2014, 311, 183-192. [CrossRef] [PubMed]

2. GBD 2013 Risk Factors Collaborators; Forouzanfar, M.H.; Alexander, L.; Anderson, H.R.; Bachman, V.F.; Biryukov, S.; Brauer, M.; Burnett, R.; Casey, D.; Coates, M.M.; et al. Global, regional, and national comparative risk assessment of 79 behavioural, environmental and occupational, and metabolic risks or clusters of risks in 188 countries, 1990-2013: A systematic analysis for the Global Burden of Disease Study 2013. Lancet 2015, 386, 2287-2323. [CrossRef]

3. US Department of Health and Human Services. Preventing Tobacco Use among Youth and Young Adults: A Report of the Surgeon General 2012. Available online: http:/ /www.surgeongeneral.gov/library/reports/ preventing-youth-tobacco-use/ (accessed on 21 February 2016). 
4. $\quad$ Pierce, J.P.; Choi, W.S.; Gilpin, E.A.; Farkas, A.J.; Merritt, R.K. Validation of susceptibility as a predictor of which adolescents take up smoking in the United States. Health Psychol. 1996, 15, 355-361. [CrossRef] [PubMed]

5. Choi, W.S.; Gilpin, E.A.; Farkas, A.J.; Pierce, J.P. Determining the probability of future smoking among adolescents. Addiction 2001, 96, 313-323. [CrossRef] [PubMed]

6. Wakefield, M.; Kloska, D.D.; O’Malley, P.M.; Johnston, L.D.; Chaloupka, F.; Pierce, J.; Giovino, G.; Ruel, E.; Flay, B.R. The role of smoking intentions in predicting future smoking among youth: Findings from Monitoring the Future data. Addiction 2004, 99, 914-922. [CrossRef] [PubMed]

7. Azagba, S.; Asbridge, M. School connectedness and susceptibility to smoking among adolescents in Canada. Nicotine Tob. Res. 2013, 15, 1458-1463. [CrossRef] [PubMed]

8. Veeranki, S.P.; Mamudu, H.M.; Anderson, J.L.; Zheng, S. Worldwide never-smoking youth susceptibility to smoking. J. Adolesc. Health 2014, 54, 144-150. [CrossRef] [PubMed]

9. Dube, S.R.; Arrazola, R.A.; Lee, J.; Engstrom, M.; Malarcher, A. Pro-tobacco influences and susceptibility to smoking cigarettes among middle and high school students-United States, 2011. J. Adolesc. Health 2013, 52 (Suppl. 5), S45-S51. [CrossRef] [PubMed]

10. Goniewicz, M.L.; Knysak, J.; Gawron, M.; Kosmider, L.; Sobczak, A.; Kurek, J.; Prokopowicz, A.; Jablonska-Czapla, M.; Rosik-Dulewska, C.; Havel, C.; et al. Levels of selected carcinogens and toxicants in vapour from electronic cigarettes. Tob. Control 2014, 23, 133-139. [CrossRef] [PubMed]

11. Bullen, C.; Howe, C.; Laugesen, M.; McRobbie, H.; Parag, V.; Williman, J.; Walker, N. Electronic cigarettes for smoking cessation: A randomised controlled trial. Lancet 2013, 382, 1629-1637. [CrossRef]

12. Grana, R.; Benowitz, N.; Glantz, S.A. E-cigarettes: A scientific review. Circulation 2014, 129, $1972-1986$. [CrossRef] [PubMed]

13. Adkison, S.E.; O'Connor, R.J.; Bansal-Travers, M.; Hyland, A.; Borland, R.; Yong, H.H.; Cummings, K.M.; McNeill, A.; Thrasher, J.F.; Hammond, D.; et al. Electronic nicotine delivery systems: International tobacco control four-country survey. Am. J. Prev. Med. 2013, 44, 207-215. [CrossRef] [PubMed]

14. Manzoli, L.; Flacco, M.E.; Fiore, M.; La Vecchia, C.; Marzuillo, C.; Gualano, M.R.; Ligurori, G.; Cicolini, G.; Capasso, L.; D'Amario, C.; et al. Electronic Cigarettes Efficacy and Safety at 12 Months: Cohort Study. PLoS ONE 2015, 10, e0129443. [CrossRef] [PubMed]

15. Gravely, S.; Fong, G.T.; Cummings, K.M.; Yan, M.; Quah, A.C.; Borland, R.; Yong, H.H.; Hitchman, S.C.; Mc Neill, A.; Hammond, D.; et al. Awareness, trial, and current use of electronic cigarettes in 10 countries: Findings from the ITC project. Int. J. Environ. Res. Public Health 2014, 11, 11691-11704. [CrossRef] [PubMed]

16. McMillen, R.C.; Gottlieb, M.A.; Shaefer, R.M.; Winickoff, J.P.; Klein, J.D. Trends in Electronic Cigarette Use among U.S. Adults: Use is Increasing in Both Smokers and Nonsmokers. Nicotine Tob. Res. 2015, 17, 1195-1202. [CrossRef] [PubMed]

17. Agaku, I.T.; King, B.A.; Husten, C.G.; Bunnell, R.; Ambrose, B.K.; Hu, S.S.; Holder-Hayes, E.; Day, H.R. Center for Disease Control and Prevention (CDC). Tobacco product use among adults-United States, 2012-2013. MMWR Morb. Mortal Wkly. Rep. 2014, 63, 542-547. [PubMed]

18. Reid, J.L.; Rynard, V.L.; Czoli, C.D.; Hammond, D. Who is using e-cigarettes in Canada? Nationally representative data on the prevalence of e-cigarette use among Canadians. Prev. Med. 2015, 81, 180-183. [CrossRef] [PubMed]

19. Carroll Chapman, S.L.; Wu, L.T. E-cigarette prevalence and correlates of use among adolescents versus adults: A review and comparison. J. Psychiatr. Res. 2014, 54, 43-54. [CrossRef] [PubMed]

20. Dutra, L.M.; Glantz, S.A. Electronic cigarettes and conventional cigarette use among U.S. adolescents: A cross-sectional study. JAMA Pediatr. 2014, 168, 610-617. [CrossRef] [PubMed]

21. Leventhal, A.M.; Strong, D.R.; Kirkpatrick, M.G.; Unger, J.B.; Sussman, S.; Riggs, N.R.; Stone, M.D.; Khoddam, R.; Samet, J.M.; Audrain-McGoven, J. Association of Electronic Cigarette Use With Initiation of Combustible Tobacco Product Smoking in Early Adolescence. JAMA 2015, 314, 700-707. [CrossRef] [PubMed]

22. Bunnell, R.E.; Agaku, I.T.; Arrazola, R.A.; Apelberg, B.J.; Caraballo, R.S.; Corey, C.G.; Coleman, B.N.; Dube, S.R.; King, B.A. Intentions to smoke cigarettes among never-smoking US middle and high school electronic cigarette users: National Youth Tobacco Survey, 2011-2013. Nicotine Tob. Res. 2015, 17, 228-235. [CrossRef] [PubMed] 
23. Coleman, B.N.; Apelberg, B.J.; Ambrose, B.K.; Green, K.M.; Choiniere, C.J.; Bunnell, R.; King, B.A. Association between electronic cigarette use and openness to cigarette smoking among US young adults. Nicotine Tob. Res. 2015, 17, 212-218. [CrossRef] [PubMed]

24. Wang, M.P.; Ho, S.Y.; Leung, L.T.; Lam, T.H. Electronic cigarette use and its association with smoking in Hong Kong Chinese adolescents. Addict. Behav. 2015, 50, 124-127. [CrossRef] [PubMed]

25. Moore, G.F.; Littlecott, H.J.; Moore, L.; Ahmed, N.; Holliday, J. E-cigarette use and intentions to smoke among 10-11-year-old never-smokers in Wales. Tob. Control 2014. [CrossRef] [PubMed]

26. Wills, T.A.; Sargent, J.D.; Knight, R.; Pagano, I.; Gibbons, F.X. E-cigarette use and willingness to smoke: A sample of adolescent non-smokers. Tob. Control 2015. [CrossRef] [PubMed]

27. Primack, B.A.; Soneji, S.; Stoolmiller, M.; Fine, M.J.; Sargent, J.D. Progression to Traditional Cigarette Smoking After Electronic Cigarette Use Among US Adolescents and Young Adults. JAMA Pediatr. 2015, 169, 1018-1023. [CrossRef] [PubMed]

28. Stroup, D.F.; Berilin, J.A.; Morton, S.C.; Olkin, I.; Williamson, G.D.; Rennie, D.; Moher, D.; Becker, B.J.; Sipe, T.A.; Thacker, S.B. Meta-analysis of observational studies in epidemiology: A proposal for reporting. Meta-analysis of Observational Studies in Epidemiology (MOOSE) group. JAMA 2000, 283, 2008-2012. [CrossRef] [PubMed]

29. Higgins, J.P.; Thompson, S.G.; Deeks, J.J.; Altman, D.G. Measuring inconsistency in meta-analyses. BMJ 2013, 327, 557-560. [CrossRef] [PubMed]

30. DerSimonian, R.; Laird, N. Meta-analysis in clinical trials. Control. Clin. Trials 1986, 7, 177-188. [CrossRef]

31. Fairchild, A.L.; Bayer, R.; Colgrove, J. The renormalization of smoking? E-cigarettes and the tobacco “endgame". N. Engl. J. Med. 2014, 370, 293-295. [CrossRef] [PubMed]

32. Grana, R.A. Electronic cigarettes: A new nicotine gateway? J. Adolesc. Health 2013, 52, 135-136. [CrossRef] [PubMed]

33. Zhan, W.; Dierker, L.C.; Rose, J.S.; Selya, A.; Mermelstein, R.J. The natural course of nicotine dependence symptoms among adolescent smokers. Nicotine Tob. Res 2012, 14, 1445-1452. [CrossRef] [PubMed]

34. Durmowicz, E.L. The impact of electronic cigarettes on the paediatric population. Tob. Control 2014, 23 (Suppl. 2), ii41-ii46. [CrossRef] [PubMed]

35. Ramôa, C.P.; Hiler, M.M.; Spindle, T.R.; Lopez, A.A.; Karaoghlanian, N.; Lipato, T.; Breland, A.B.; Shihadeh, A.; Eissenberg, T. Electronic cigarette nicotine delivery can exceed that of combustible cigarettes: A preliminary report. Tob. Control 2015. [CrossRef] [PubMed]

36. Farsalinos, K.E.; Spyrou, A.; Tsimopoulou, K.; Stefopoulos, C.; Romagna, G.; Voudris, V. Nicotine absorption from electronic cigarette use: Comparison between first and new-generation devices. Sci. Rep. 2014, 4, 4133. [CrossRef] [PubMed]

37. Okoli, C.T.; Kodet, J. A systematic review of secondhand tobacco smoke exposure and smoking behaviors: Smoking status, susceptibility, initiation, dependence, and cessation. Addict. Behav. 2015, 47, 22-32. [CrossRef] [PubMed]

38. Czogala, J.; Goniewicz, M.L.; Fidelus, B.; Zielinska-Danch, W.; Travers, M.J.; Sobczak, A. Secondhand exposure to vapors from electronic cigarettes. Nicotine Tob. Res. 2014, 16, 655-662. [CrossRef] [PubMed]

39. McAuley, T.R.; Hopke, P.K.; Zhao, J.; Babaian, S. Comparison of the effects of e-cigarette vapor and cigarette smoke on indoor air quality. Inhal. Toxicol. 2012, 24, 850-857. [CrossRef] [PubMed]

40. Veeranki, S.P.; Mamudu, H.M.; Zheng, S.; John, R.M.; Cao, Y.; Kioko, D.; Anderson, J.; Ouma, A.E. Secondhand smoke exposure among never-smoking youth in 168 countries. J. Adolesc. Health 2015, 56, 167-173. [CrossRef] [PubMed]

41. Choi, K.; Forster, J. Characteristics associated with awareness, perceptions, and use of electronic nicotine delivery systems among young US Midwestern adults. Am. J. Public Health 2013, 103, 556-561. [CrossRef] [PubMed]

42. Leonardi-Bee, J.; Jere, M.L.; Britton, J. Exposure to parental and sibling smoking and the risk of smoking uptake in childhood and adolescence: A systematic review and meta-analysis. Thorax 2011, 66, 847-855. [CrossRef] [PubMed]

(C) 2016 by the authors; licensee MDPI, Basel, Switzerland. This article is an open access article distributed under the terms and conditions of the Creative Commons Attribution (CC-BY) license (http://creativecommons.org/licenses/by/4.0/). 